\title{
Physiological Ecology
}





\section{Physiological Ecology}

How Animals Process Energy, Nutrients, and Toxins

\section{William H. Karasov and Carlos Martínez del Rio}


Copyright (C) 2007 by Princeton University Press

Published by Princeton University Press, 41 William Street, Princeton, New Jersey 08540

In the United Kingdom: Princeton University Press, 3 Market Place, Woodstock, Oxfordshire OX20 1SY

All Rights Reserved

\section{Library of Congress Cataloging-In-Publication Data}

Karasov, William H., 1953-

Physiological ecology: how animals process energy, nutrients, and toxins/William H. Karasov and Carlos Martínez del Rio.

$$
\text { p. cm. }
$$

Includes index.

ISBN-13: 978-0-691-07453-5 (clothbound: alk. paper)

ISBN-10: 0-691-07453-4 (clothbound : alk. paper) 1. Animal ecophysiology.

I. Martínez del Rio, Carlos, 1956- II. Title.

QP82.K34 2006

$591.7-\mathrm{DC} 22$

2006037344

British Library Cataloging-in-Publication Data is available

This book has been composed in Adobe Caslon

Printed on acid-free paper.

$$
\text { press.princeton.edu }
$$

Printed in the United States of America

$$
135579108642
$$

